\title{
Aquatic Invertebrate Surveys and Assessment of Stream Sites in the Centennial Valley, Beaverhead Co., MT
}

\author{
Prepared for The Nature Conservancy of Montana
}

by

David M. Stagliano

Aquatic Ecologist

March 2012

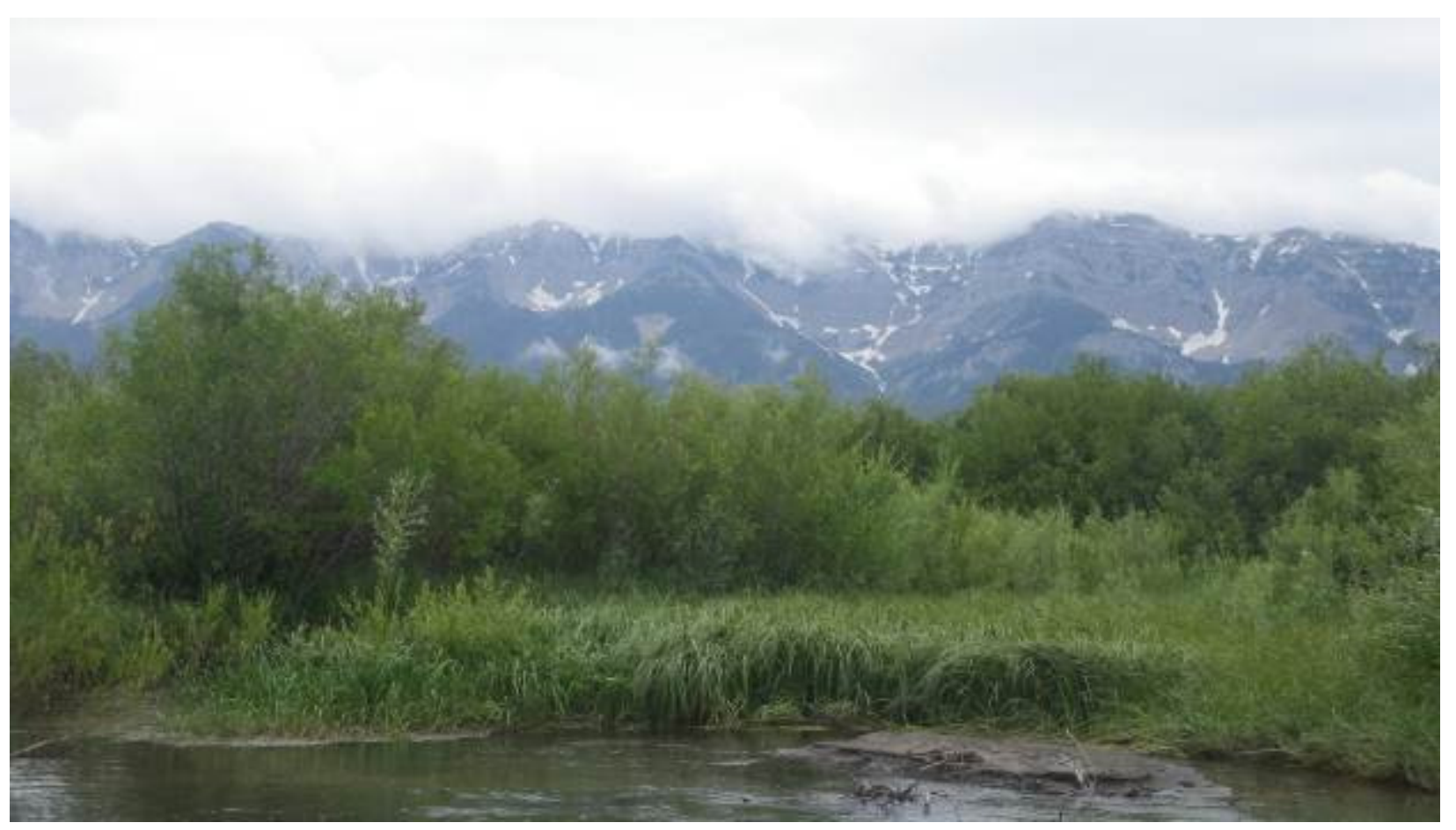

Red Rock Creek looking south to the Alaska Basin

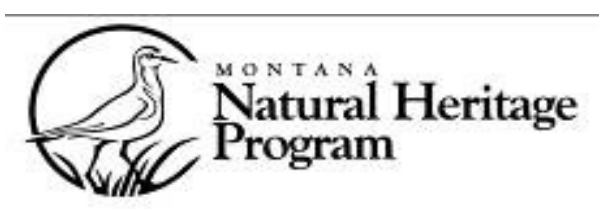

a program of the Montana State Library's Natural Resource Information System operated by the University of Montana 


\section{Project Summary}

Project goals of the 2011 TNC Centennial Valley Aquatic Survey and Assessment were to: 1) determine if Western Pearlshell mussels or other unique/SOC invertebrate taxa are present or may have been previously present in selected streams of the basin and 2) collect baseline data and assess aquatic community integrity within stream restoration reaches based on macroinvertebrate communities, in-stream habitat characteristics and basic water chemistry data. A previous macroinvertebrate collection on Long Creek was performed in 2009 (Anderson, unpublished data), but due to inadequate and unrepeatable methods for macroinvertebrate processing (timed hand-picking of live organisms with unaided eye at the site), meaningful comparisons cannot be made to this data.

\section{Habitat Evaluations.}

On-site habitat assessments were conducted using the rapid assessment protocol by the BLM (http://www1.usu.edu/buglab/forms/Bug\%20Protocol\%20form.pdf). Using this assessment, the reach was divided into 10 equally spaced transects. Parameters recorded at each were: wetted width, left, center and right channel depth measurements, percent large woody debris and riparian shading. Basic water chemistry parameters (temperature, $\mathrm{pH}$, conductivity) were recorded prior to macroinvertebrate sampling using a Horiba H-10 water monitor. The goal of these evaluations is to characterize local reach geomorphology, riparian and in-stream habitat, and other characteristics that influence aquatic community integrity. Sites ranking higher using these protocols are determined to have higher quality local-scale habitat.

\section{Mussel Surveys.}

Mussels were surveyed in three streams (8 reaches) of the Centennial Valley using a catch-perunit-effort (CPUE) or catch per linear distance (CPUD) approach, because the emphasis of our study is to determine western pearlshell presence/absence and relative abundance. Time searched by the number of surveyors is expressed as number of mussels per person-hour and a measured stream distance traveled can be converted to mussels per linear meter of stream (mussels per 50 stream meters). We devoted approximately one man-hour of search per site and an effort was made to sample multiple geomorphic units (riffle, glide and pool sequences) and all available habitats therein. Visual surveys were conducted along a series of $50 \mathrm{~m}$ transects searched along the longitudinal length of the stream (Young et al. 2001). The longitudinal transect survey technique with side searching enables two surveyors to effectively search an entire cross-section of the stream channel when wetted widths are less than $\sim 6 \mathrm{~m}$.

\section{Macroinvertebrate Communities.}

Macroinvertebrates were collected from riffle sections within designated reaches with a 500micron D-frame dipnet. The method utilized was the EMAP Targeted Riffle sample protocol

outlined in Lazorchak et al. (1998). Eight discrete area $\left(8 \mathrm{ft}^{2}\right.$ or $\left.0.7432 \mathrm{~m}^{2}\right)$ samples randomly configured $(2,3,2)$ within the 3 riffles were composited into a bucket, substrates were scrubbed 
clean and the organisms were collected onto a 500-micron sieve, transferred to a 1 liter Nalgene bottle, labeled, preserved in 95\% ethanol and transported to the MTNHP lab in Helena for processing. The samples were processed (sorting, identification, and data analysis) by D. Stagliano following MT Department of Environmental Quality's protocols (MT DEQ 2005). Macroinvertebrates were picked completely from randomly chosen Caton tray grids under a low power microscope (3-10x) until at least 500 individuals were reached and the number of grids selected was recorded. These organisms were then identified to the lowest taxonomic level (genus/species), imported into EDAS (Jessup 2006), and biological metrics were calculated from the data using the newest multimetric (MMI) protocols (Jessup et al. 2005, Feldman 2006). A battery of seven richness, trophic and sensitivity metrics are calculated by this database application. One such metric, the Hilsenhoff Biotic Index (HBI) uses tolerance values to weigh abundance of invertebrates in an estimate of "tolerance to pollution". Originally designed to evaluate organic pollution, it has been shown to be correlated to increases in benthic sediments as well as nutrients (Barbour et al. 1995). Metric results were scored using the Montana DEQ bioassessment criteria and each sample categorized (Table 1) (Feldman et al. 2006).

\begin{tabular}{|c|c|c|c|}
\hline Ecoregion & AIVPACS & MM| & |mpairment Determination \\
\hline Mountair & $\begin{array}{l}\geq 0.8 \text { or } \leq 1.2 \\
<0.8 \text { or }>1.2\end{array}$ & $\begin{array}{l}\geq 63 \\
<63\end{array}$ & $\begin{array}{l}\text { Wot impaired } \\
\text { lmpaired }\end{array}$ \\
\hline Low Valley & $\begin{array}{l}\geq 0.8 \text { or } \leq 1.2 \\
<0.8 \text { or }>1.2\end{array}$ & $\begin{array}{l}\geq 48 \\
<48\end{array}$ & $\begin{array}{l}\text { Not impaired } \\
\text { Impaired }\end{array}$ \\
\hline Eastern Plains & $\begin{array}{l}\geq 0.8 \text { or } \leq 1.2 \\
<0.8 \text { or }>1.2\end{array}$ & $\begin{array}{l}\geq 37 \\
<37\end{array}$ & $\begin{array}{l}\text { Not impaired } \\
\text { Impaired }\end{array}$ \\
\hline
\end{tabular}

The impairment threshold set by MT DEQ is $\mathbf{4 8}$ for the Low Mountain/Valley Index, thus any scores above this threshold are considered unimpaired. These Centennial Valley streams should be categorized as Low Mountain / Valley sites, but we will also run the Hellroaring Creek metrics using the DEQ Mountain MMI as an alternate scoring method. The macroinvertebrate MMI score is based upon a series of metrics that measure attributes of benthic macroinvertebrate communities regarding condition changes to a stream system (in the form of anthropogenic caused changes).

\section{Sites}

All sites visited 7/31-8/1/2011 for this TNC assessment lie in the Red Rock River $4^{\text {th }}$ code HUC 10020001 in Beaverhead County, MT. Habitat assessments, water quality measurements, macroinvertebrate sampling and mussel surveys were performed at three pre-determined Long Creek sites and two additional stream restoration sites on Hellroaring Creek (per conversation with Nathan Korb). Three longitudinal sequence reaches were sampled in Longs Creek 
(Transplant (L), Passive (M) and Container Reach (U)) and two in Hellroaring Creek (Upper and Mid-Reach). Additional mussel surveys were conducted on two reaches of Red Rock and lower Long Creek, but other biological assessments were not performed.

Table 2. Stream Station information. Start/End Stream Survey Reach, Location Description. Elevation in feet and the approximate stream reach length walked during survey.

\begin{tabular}{|c|c|c|c|c|c|c|c|c|}
\hline site_code & Stream & Start_Lat & Start_Long & Lat_End & Long_End & Location & Elevation & $\begin{array}{l}\text { Appx. Survey } \\
\text { Distance (m) }\end{array}$ \\
\hline UM_RRTNCa & Red Rock Creek & 44.6175 & -111.6561 & & & $\begin{array}{l}\text { Red Rock Creek bridge at the NWR } \\
\text { boundary upstream in the valley }\end{array}$ & 6650 & 300 \\
\hline UM_RRTNCb & Red Rock Creek & 44.6113 & -111.6132 & & & $\begin{array}{l}\text { Red Rock Creek willow area at the } \\
\text { state section further upstream }\end{array}$ & 6722 & 300 \\
\hline UMHELRCm & Hell Roaring Creek & 44.6068 & -111.5531 & & & $\begin{array}{l}\text { Downstream of Red Rock Pass Rd, } \\
\text { mid reach TNC bug sample }\end{array}$ & 6843 & 150 \\
\hline UMHELRCu & Hell Roaring Creek & 44.6003 & -111.5509 & & & $\begin{array}{l}\text { D/S of Red Rock Pass Rd, upper } \\
\text { restoration reach TNC bug sample }\end{array}$ & 6873 & 150 \\
\hline UMLNGTNC1 & Long Creek & 44.6672 & -112.1052 & 44.6681 & -112.1038 & $\begin{array}{l}\text { Long Creek TNC property lower site, } \\
\text { transplant reach, fenceline upstream } \\
\text { to end of transplant reach }\end{array}$ & 6637 & 300 \\
\hline UMLNGTNC2 & Long Creek & 44.6775 & -112.1057 & 44.6785 & -112.1050 & $\begin{array}{l}\text { Long Creek TNC property middle } \\
\text { site, passive reach }\end{array}$ & 6699 & 500 \\
\hline UMLNGTNC3 & Long Creek & 44.6861 & -112.1040 & 44.6861 & -112.1040 & $\begin{array}{l}\text { Long Creek TNC property upper site, } \\
\text { container reach, }\end{array}$ & 6709 & 300 \\
\hline UMLNGTNC4 & Long Creek & 44.6527 & -112.1060 & 44.6514 & -112.1059 & $\begin{array}{l}\text { At the north valley road bridge } \\
\text { upstream \& downstream }\end{array}$ & 6624 & 200 \\
\hline
\end{tabular}

\section{Habitat Evaluations.}

\section{Results}

Highest site habitat scores were measured in the Red Rock Creek willow-dominated, proper functioning riparian (PFC) reach on the DNRC state section (UM_RRTNCa)/NWR boundary, followed by the upstream Red Rock Creek site (UM_RRTNCb). Lowest riparian integrity scores were recorded from Long Creek at the valley road and the lower transplant site (Table 3). Hellroaring Creek's mid-reach riparian area also scored relatively degraded and Functional-AtRisk (FAR) with the BLM Habitat Assessment due to sloughing, unstable banks and lack of riparian vegetation. Water quality parameters, conductivity and $\mathrm{pH}$, were fairly uniform (fall within a normal range) across all stream sites ranging from the lowest conductivity at Hellroaring Creek $(184 \mu \mathrm{s} / \mathrm{sec})$ to higher values at Long Creek down from the county road (438 $\mu \mathrm{s} / \mathrm{sec})$. Warmest water temperature measured was $17.3^{\circ} \mathrm{C}$ at the furthest downstream Long Creek site at north valley road in the evening of $7 / 31$ (Table 3 ). 
Table 3. Water temp in ${ }^{\circ} \mathrm{C}$, Cond=conductivity in $\mu \mathrm{s} / \mathrm{sec}$. BLM Hab $=$ Habitat Health assessment rank by riparian/stream evaluations (++) = good-excellent (PFC), (+) fair (FARi), (-) poor (FAR, FARd). Bug Sample $(+)=$ taken at site, $(-)$-not taken. Mussels present $(+)$ or absent $(-)$.

\begin{tabular}{|ccccc|ccc|}
\hline Site ID & \multicolumn{1}{c}{ Name } & $\begin{array}{c}\mathbf{H}_{\mathbf{2}} \mathbf{0} \\
\text { Temp }\end{array}$ & $\begin{array}{c}\text { Cond } \\
\text { pH }\end{array}$ & $\begin{array}{c}\text { BLM } \\
\text { Habitat }\end{array}$ & $\begin{array}{c}\text { Bug } \\
\text { Sample }\end{array}$ & $\begin{array}{c}\text { Mussels } \\
\text { Present }\end{array}$ \\
\hline UM_RRTNCa & Red Rock Cr. (I) & 10.8 & 249.0 & 6.5 & $\mathbf{+ +}$ & $\mathbf{-}$ & $\mathbf{-}$ \\
UM_RRTNCb & Red Rock Cr. (u) & 10.8 & 248.0 & 6.5 & $\mathbf{+ +}$ & $\mathbf{-}$ & $\mathbf{-}$ \\
UMHELRCm & Hell Roaring (mid) & 9.8 & 184.0 & 7.1 & $\mathbf{-}$ & $\mathbf{+}$ & $\mathbf{-}$ \\
UMHELRCu & Hell Roaring (up) & 9.8 & 184.0 & 7.1 & $\mathbf{+}$ & $\mathbf{+}$ & $\mathbf{-}$ \\
UMLNGTNC1 & Long Creek (T) & 13.2 & 430.0 & 7.4 & $\mathbf{-}$ & $\mathbf{+}$ & $\mathbf{-}$ \\
UMLNGTNC2 & Long Creek (P) & 13.2 & 439.0 & 7.2 & $\mathbf{+}$ & $\mathbf{+}$ & $\mathbf{-}$ \\
UMLNGTNC3 & Long Creek (U) & 14.7 & 438.0 & 7.2 & $\mathbf{+}$ & $\mathbf{+}$ & $\mathbf{-}$ \\
UMLNGTNC4 & Long Creek (RD) & 17.3 & 438.0 & 7.4 & $\mathbf{-}$ & $\mathbf{-}$ & $\mathbf{-}$ \\
\hline
\end{tabular}

\section{Mussel Surveys.}

No evidence of western pearlshell mussels (live, dead or shells) was reported during the eight reach surveys in these three streams. We failed to even find shell fragments which may have indicated a previous historical population to have existed in the Centennial Valley. Long Creek has extensive reaches of preferred gravel habitat for the western pearlshell mussel (Rosgen C4 \& E4) (Stagliano 2010); thus, once the banks become stabilized and trout populations rebound, this stream may be considered as an introduction site for western pearlshells in the future.

\section{Fish Communities.}

Fish were not specifically targeted in our surveys, but we did record 2 fish species, the longnose dace (Rhinichthys cataractae) and the Rocky Mountain sculpin (Cottus cf. bondi), while surveying for mussels in the Long Creek restoration sites. Longnose dace were sparse in the lower Longs Creek reach, while sculpin were quite abundant; especially in the upper container reach (25 individuals reported in $150 \mathrm{~m}$, that's $\sim 167$ sculpin per kilometer!).

\section{Macroinvertebrate Communities.}

Species Diversity. Overall, 103 macroinvertebrate taxa were reported from five sites (seven samples) collected within the TNC Centennial Basin (Appendix A). Average macroinvertebrate taxa richness per site was 37.4 and the highest taxa richness was reported in the Long Creek passive reach replicate sample (50 taxa). Rare or infrequently collected taxa include the MT Potential Species of Concern (PSOC) caddisfly: Agapetus montanus (G3S3), collected at the Long Creek passive and transplant reaches in good numbers (Appendix A). Another infrequently collected caddisfly, Amphicomoecus canax was reported from the upper Long Creek site. One introduced crustacean species, the wide-ranging amphipod Hyalella, was reported from the Long Creek passive reach. The unique, snail-cased caddisfly, Helicopsyche borealis was collected in good numbers from all reaches of Long Creek (Appendix A).

- Ephemeroptera, Plecoptera, and Trichoptera taxa (EPT Index) were fairly abundant and diverse in Long Creek (avg. 16.8 taxa with a max of 20 species), but were much less 
diverse than for Hellroaring Creek (avg. 14 taxa) (Table 4). This value is significantly less diverse than expected compared to reference condition low mountain streams. But the \% EPT contribution to the total number of organisms in the sample was highest in Hellroaring Creek (avg. 86\%), while in Long Creek, \% EPT was much lower, averaging $\sim 40 \%$ across all samples.

- Diptera (mostly in the family Chironomidae) and Coleoptera (Elmidae, riffle beetles) made up a significant portion of sample diversity and individuals at Long Creek, averaging $\sim 44 \%$ of the organisms in all samples (Table 5). This is largely due to the dominant contribution from the riffle beetle, Optioservus quadrimaculatus making up $31 \%$ and $19 \%$ of the samples for Long Creek (lower) and passive (mid) reaches, respectively.

- Mollusk species (7 spp. total), especially the fingernail clams, Pisidium sp. and Sphaerium striatinum made up a fairly high percentage of non-insect contributions to the sampled organisms in Long Creek (avg. 13.5\% of total individuals). No mollusk species were collected in Hellroaring Creek samples (Appendix A).

Table 4. Macroinvertebrate Density and Diversity Characterisitcs of the samples collected in 2011. EPT = Ephemeroptera, Plecoptera, and Trichoptera taxa.

\begin{tabular}{|l|l|c|c|c|c|c|c|c|c|c|}
\hline StationID & WaterbodyName & $\begin{array}{c}\% \\
\text { Sample } \\
\text { Picked }\end{array}$ & $\begin{array}{c}\text { Total } \\
\text { Ind. ID }\end{array}$ & $\begin{array}{c}\text { Sample } \\
\text { Density }\end{array}$ & Ind. $\mathbf{m}^{2}$ & $\begin{array}{c}\text { Total } \\
\text { Taxa }\end{array}$ & $\begin{array}{c}\text { Eph } \\
\text { Taxa }\end{array}$ & $\begin{array}{c}\text { Plec } \\
\text { Taxa }\end{array}$ & $\begin{array}{c}\text { Trich } \\
\text { Taxa }\end{array}$ & $\begin{array}{c}\text { Total } \\
\text { EPT }\end{array}$ \\
\hline UMHELRCm & Hellroaring Cr. (mid) & 100 & 365 & 365 & 493 & 23 & 5 & 2 & 5 & 12 \\
\hline UMHELRCu & Hellroaring Cr. (upper) & 33 & 557 & 1671 & 2256 & 22 & 6 & 3 & 8 & 17 \\
\hline UMLNGTNC1 & Long Creek (Lower) & 16.7 & 521 & 3126 & 4220 & 43 & 8 & 1 & 9 & 18 \\
\hline UMLNGTNC1r & Long Creek (Lower) rep & 16.7 & 502 & 3012 & 4066 & 45 & 11 & 1 & 8 & 20 \\
\hline UMLNGTNC2 & Long Creek (passive) & 25 & 616 & 2464 & 3326 & 44 & 8 & 2 & 7 & 17 \\
\hline UMLNGTNC2r & Long Creek (passive) rer & 37.5 & 621 & 1656 & 2236 & 50 & 8 & 2 & 7 & 17 \\
\hline UMLNGTNC3 & Long Creek (upper) & 66.7 & 527 & 791 & 1067 & 35 & 5 & 1 & 6 & 12 \\
\hline
\end{tabular}

Macroinvertebrate Density. Highest macroinvertebrate densities were recorded at the Long Creek Lower Transplant reach averaging 4,140 individuals per $\mathrm{m}^{2}$, but most of these were nonEPT taxa (i.e., not preferred salmonid food) (Table 4). Densities of benthic macroinvertebrates appear to be significantly decreasing as you proceed upstream in the Long Creek reach (Figure 1). Low numbers of invertebrates $\left(<500\right.$ ind. per $\mathrm{m}^{2}$ ) were reported at the Hellroaring Creek midreach site, while the upper Hellroaring site macroinvertebrate densities were about average for this stream type (Table 4). Since the benthic area where macroinvertebrates are collected is standardized with this protocol, low numbers in the samples (i.e., substrate) usually indicate some impairment in stream benthic habitat or water quality. 
Figure 1. Macroinvertebrate Densities (Ind. $\mathrm{m}^{-2}$ ) for Long Creek sites and replicates (n=5).

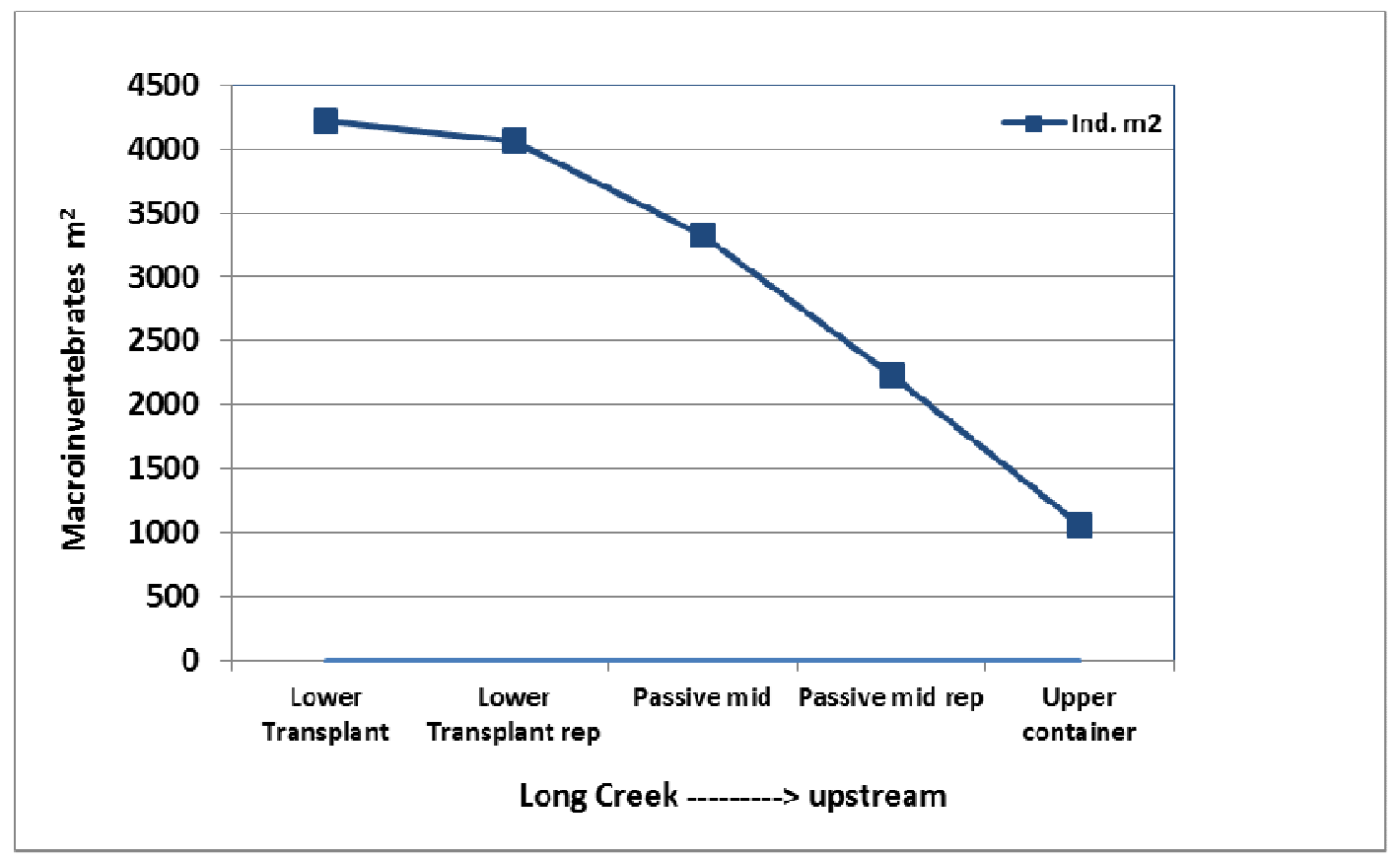

\section{Macroinvertebrate Biointegrity.}

Using the MTDEQ multimetric low mountain/valley index (LVAL MMI), all three Long Creek sites (5 samples) were ranked slightly-impaired (Scores $<48$ ), while the Hellroaring Creek reach samples were ranked un-impaired using both MMI models (>63 Mtn MMI and >48 LVAL) (Table 5). Although, the Hellroaring Creek mid-reach sample scored just above the impairment threshold and contains biotic indicators (i.e., EPT, HBI) with scores similar to impaired stream reaches $(\mathrm{EPT}=12, \mathrm{HBI}>2)$, and much lower scores than the upper reach sampled.

- Long Creek sites all reported HBI scores that were $>4.0$ indicating more tolerant macroinvertebrate communities responding to elevated nutrient or sediment levels in the substrates. High nitrogen levels can be inferred from the presence of numerous and large Nostoc (Cyanobacteria) colonies and the chironomid midge, Nostococladius which lives within them (see Photo 1).

- No significant pattern in community biointegrity was noted in the longitudinal sampling as was seen with the macroinvertebrate densities, except a slight increase from the passive to the upper reach. But despite any real pattern, baseline data shows all samples from the Long Creek sites were ranked slightly impaired (Figure 2).

- No sensitive mayfly taxa were reported in any of the Long Creek samples, and in fact, most taxa in the mayfly community were sediment tolerant species, such as Acentrella insignificans, Attenella margarita, Baetis flavistriga, Caenis latipennis and Tricorythodes minutus (Appendix A). 
Photo 1. Numerous nitrogen-fixing Nostoc colonies on benthic cobbles (red circles) and a well camouflaged Rocky Mountain Sculpin (blue circle) in Long Creek.

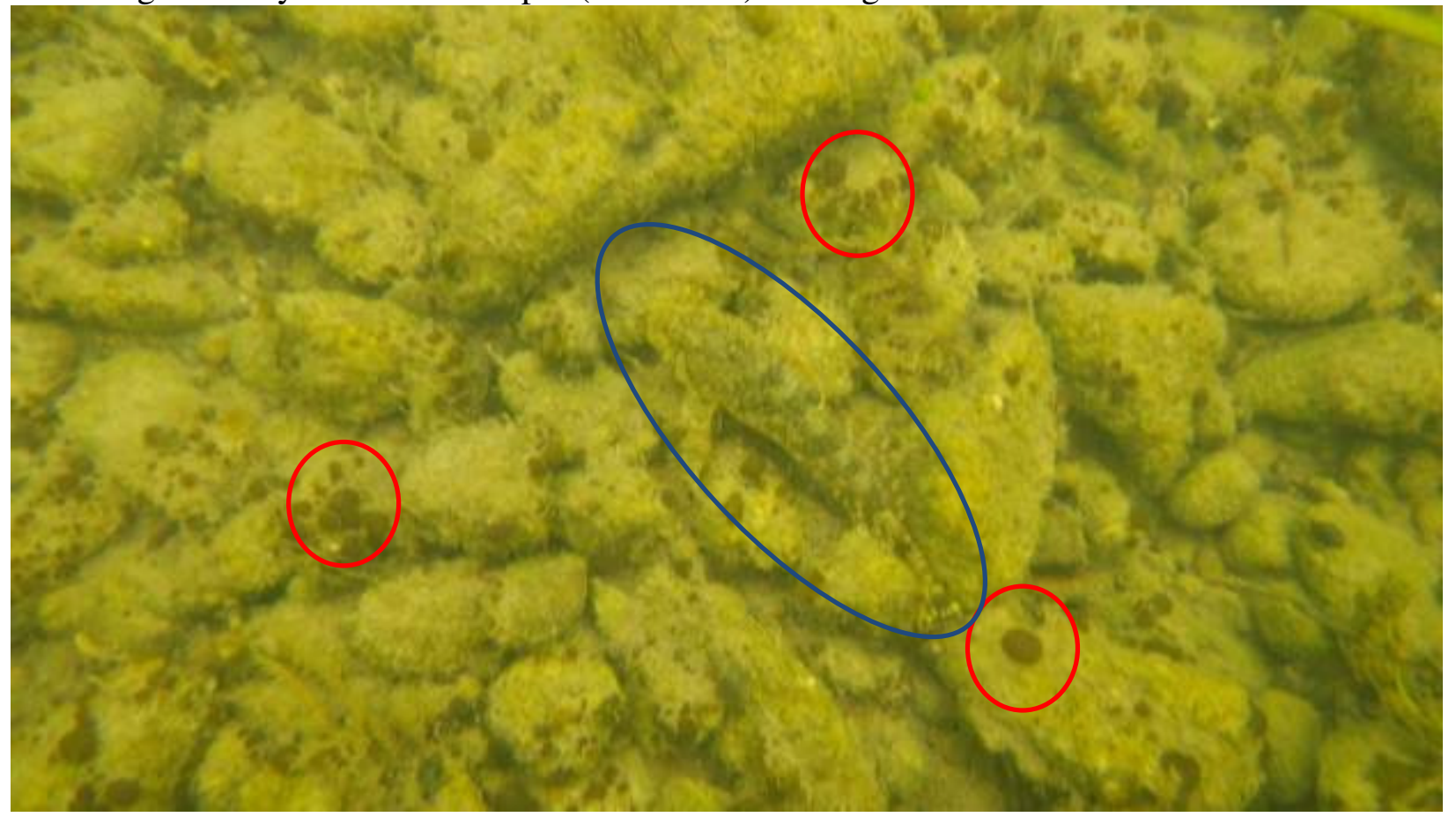

Figure 2. Macroinvertebrate MT MMI Scores for Long Creek sites and replicates (n=5). Dotted line is the MT DEQ MMI impairment threshold score (48).

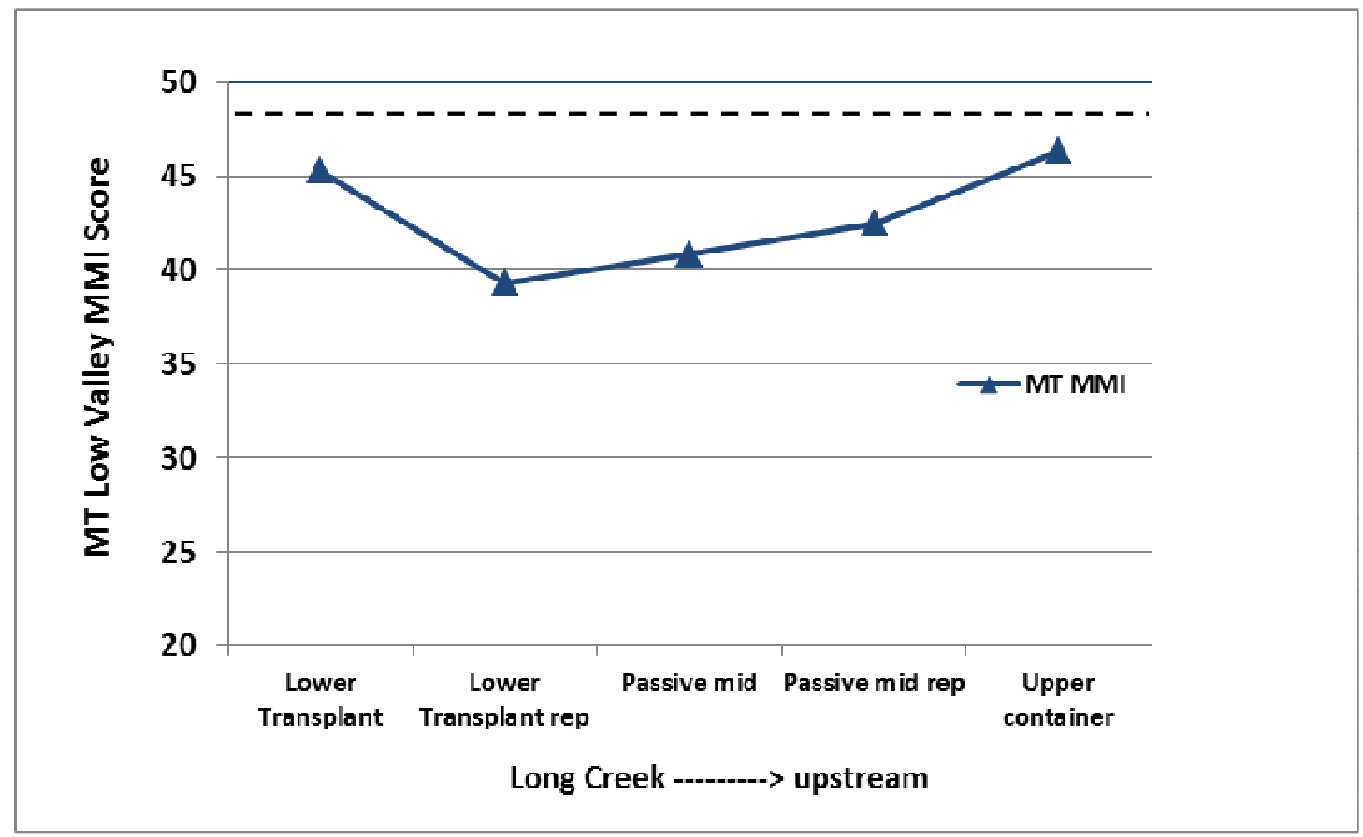


Table 5. Selected macroinvertebrate biointegrity metrics and community composition of all samples at the inventoried sites. DEQ LVAL and MTN MMI scores. HBI $=$ Hilsenhoff's Biotic Index, \% Dip/Coleop = Percent diptera and coleoptera organisms in the sample, \% NonIns= Percent non-insect organisms comprising the samples, \% CrusMol= Percent Crustacean and Mollusk organisms in the sample. Shaded-cells represent good to excellent scores above set thresholds. $\mathrm{Nc}=$ scores not calculated.

\begin{tabular}{|c|c|c|c|c|c|c|c|c|c|}
\hline StationID & WaterbodyName & $\begin{array}{l}\text { LowVal } \\
\text { Index }\end{array}$ & $\begin{array}{l}\text { Mtn } \\
\text { Index }\end{array}$ & $\mathrm{HBI}$ & $\%$ EPT & $\begin{array}{l}\text { \% Dip/ } \\
\text { Coleop }\end{array}$ & $\begin{array}{c}\% \\
\text { Elmidae }\end{array}$ & $\begin{array}{c}\% \\
\text { Nonlns }\end{array}$ & $\begin{array}{c}\% \\
\text { CrusMol }\end{array}$ \\
\hline UMHELRCm & Hellroaring Cr. (mid) & 63.7 & 65.6 & 2.6 & 78.9 & 18.1 & 0.00 & 3.0 & 0.0 \\
\hline UMHELRCu & Hellroaring Cr. (upper) & 65.3 & 74.6 & 1.6 & 95.3 & 4.7 & 0.00 & 0.0 & 0.0 \\
\hline UMLNGTNC1 & $\begin{array}{l}\text { Long Creek (Lower) } \\
\text { Long Creek (Lower) }\end{array}$ & 45.3 & $\mathrm{nc}$ & 4.6 & 41.1 & 48.8 & 0.31 & 10.2 & 8.8 \\
\hline UMLNGTNC1r & rep & 39.3 & nc & 4.7 & 39.2 & 45.8 & 0.31 & 14.9 & 13.8 \\
\hline UMLNGTNC2 & $\begin{array}{l}\text { Long Creek (passive) } \\
\text { Long Creek (passive) }\end{array}$ & 40.9 & $\mathrm{nc}$ & 4.1 & 40.9 & 46.1 & 0.19 & 13.0 & 12.2 \\
\hline UMLNGTNC2r & rep & 42.5 & $\mathrm{nc}$ & 4.2 & 39.0 & 48.8 & 0.19 & 12.2 & 11.3 \\
\hline UMLNGTNC3 & Long Creek (upper) & 46.3 & $\mathrm{nc}$ & 5.1 & 41.2 & 32.3 & 0.02 & 26.6 & 21.6 \\
\hline
\end{tabular}

Overall Aquatic Ecological System Site Condition (in order of highest to lowest integrity):

Small Transitional Stream-(AES D002)-1) Hellroaring Cr. (upper), Hellroaring Cr. (mid-reach), Georeferenced Site Photos: http://mtnhp.org/ThumbsPlus/Eco/Aquatics/TNCCenValley_2011/UMHELRCm.JPG http://mtnhp.org/ThumbsPlus/Eco/Aquatics/TNCCenValley_2011/UMHELRCm_b.JPG http://mtnhp.org/ThumbsPlus/Eco/Aquatics/TNCCenValley_2011/UMHELRCu.JPG http://mtnhp.org/ThumbsPlus/Eco/Aquatics/TNCCenValley_2011/UMHELRCu_b.JPG

Small Foothills Stream (AES C001)-1) Long Creek (upper container reach), 2) Long Creek (passive reach), 3) Long Creek (transplant reach), 4) Long Creek (below valley road) http://mtnhp.org/ThumbsPlus/Eco/Aquatics/TNCCenValley_2011/UMLNGTNC1_d.JPG http://mtnhp.org/ThumbsPlus/Eco/Aquatics/TNCCenValley_2011/UMLNGTNC1.JPG http://mtnhp.org/ThumbsPlus/Eco/Aquatics/TNCCenValley 2011/UMLNGTNC1_chara.JPG http://mtnhp.org/ThumbsPlus/Eco/Aquatics/TNCCenValley 2011/UMLNGTNC2 passive.JP http://mtnhp.org/ThumbsPlus/Eco/Aquatics/TNCCenValley_2011/UMLNGTNC2_passive2.JPG http://mtnhp.org/ThumbsPlus/Eco/Aquatics/TNCCenValley_2011/UMLNGTNC2_passive3.JPG http://mtnhp.org/ThumbsPlus/Eco/Aquatics/TNCCenValley_2011/UMLNGTNC2_passive4.JPG http://mtnhp.org/ThumbsPlus/Eco/Aquatics/TNCCenValley_2011/UMLNGTNC3.JPG http://mtnhp.org/ThumbsPlus/Eco/Aquatics/TNCCenValley_2011/UMLNGTNC3_up.JPG http://mtnhp.org/ThumbsPlus/Eco/Aquatics/TNCCenValley_2011/UMLNGTNC4_u.JPG http://mtnhp.org/ThumbsPlus/Eco/Aquatics/TNCCenValley_2011/UMLNGTNC4_d.JPG

Medium Intermountain Transitional River (AES B001)-1) Red Rock Creek (NWR boundary reach), 2) Red Rock Creek (upper state DNRC reach) http://mtnhp.org/ThumbsPlus/Eco/Aquatics/TNCCenValley_2011/UM_RRTNCa.JPG http://mtnhp.org/ThumbsPlus/Eco/Aquatics/TNCCenValley_2011/UM_RRTNCa_Akbasin.JPG 
http://mtnhp.org/ThumbsPlus/Eco/Aquatics/TNCCenValley_2011/UM_RRTNCb.JPG

http://mtnhp.org/ThumbsPlus/Eco/Aquatics/TNCCenValley_2011/UM_RRTNCb_2.JPG

http://mtnhp.org/ThumbsPlus/Eco/Aquatics/TNCCenValley_2011/UM_RRTNCb_Caddis.JPG

http://mtnhp.org/ThumbsPlus/Eco/Aquatics/TNCCenValley_2011/UM_RRTNCb_DICOS.JPG

http://mtnhp.org/ThumbsPlus/Eco/Aquatics/TNCCenValley 2011/UM_RRTNCb_lookup.JPG

\section{Acknowledgements}

We would like to thank The Montana Field Office of the Nature Conservancy for funding this survey, especially Nathan Korb, SW Montana Stewardship. Tyler Renfield, a summer intern with TNC was a great help with field work and data collection.

All photos in the report were taken by MTNHP personnel, unless otherwise noted.

\section{Literature Cited}

Feldman, D. 2006. Interpretation of New Macroinvertebrate Models by WQPB. Draft

Report. Montana Department of Environmental Quality, Planning Prevention and

Assistance Division, Water Quality Planning Bureau, Water Quality Standards Section.1520 E. $6^{\text {th }}$ Avenue, Helena, MT 59620. 14 pp.

Holton, G. D., and H. E. Johnson. 2003. A field guide to Montana fishes, 3rd edition. Montana Fish, Wildlife, and Parks, Helena.

Jessup, B., J. Stribling; and C. Hawkins. 2005. Biological Indicators of Stream Condition in Montana Using Macroinvertebrates. Tetra Tech, Inc. November 2005 (draft).

Jessup, B. 2006. Ecological Data Application System (EDAS) Version MT 3.3.2k A User's Guide. Tetra Tech, Inc.

Lazorchak, J.M., Klemm, D.J., and D.V. Peck (editors). 1998. Environmental Monitoring and Assessment Program - Surface Waters: Field Operations and Methods for Measuring the Ecological Condition of Wadeable Streams. EPA/620/R-94/004F. U.S. Environmental Protection Agency, Washington, D.C.

Montana Department of Environmental Quality (DEQ). 2005. Sample Collection, Sorting, and Taxonomic Identification of Benthic Macroinvertebrates. Water Quality Planning Bureau. Standard Operation Procedure (WQPBWQM-009).

Stagliano D.M. 2010. Freshwater Mussels in Montana: Comprehensive Results from 3 Years of SWG Funded Surveys. Montana Natural Heritage Program. Helena, MT. 69 pp.

Stagliano, David, M. 2005. Aquatic Community Classification and Ecosystem Diversity in Montana's Missouri River Watershed. Report to the Bureau of Land Management. Montana Natural Heritage Program, Helena, Montana. 65 pp. plus appendices. http://www.mtnhp.org/reports.asp\#Ecology

Young, M.R., P.J. Cosgrove, L.C. Hastie, and B. Nenniger. 2001. A standardized method for assessing the status of freshwater mussels in clear, shallow rivers. Malacol. Soc. of London 67: 395 - 396. 